\title{
Treatment of fly ash from power plants using thermal plasma
}

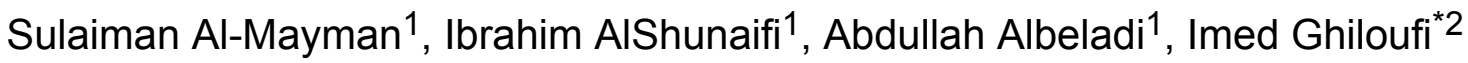 \\ and Saud Binjuwair ${ }^{1}$
}

\author{
Full Research Paper \\ Address: \\ ${ }^{1}$ King Abdulaziz City for Science and Technology (KACST), National \\ Center for Combustion \& Plasma Technology, Riyadh, Saudi Arabia \\ and ${ }^{2} \mathrm{Al}$ Imam Mohammad Ibn Saud Islamic University (IMSIU), \\ College of Sciences, Riyadh, Saudi Arabia \\ Email: \\ Imed Ghiloufi - ghiloufimed@yahoo.fr \\ * Corresponding author \\ Keywords: \\ fly ash; power plant; stabilization/solidification; surface \\ characterization; thermal plasma
}

Beilstein J. Nanotechnol. 2017, 8, 1043-1048.

doi:10.3762/bjnano.8.105

Received: 02 September 2016

Accepted: 21 April 2017

Published: 11 May 2017

This article is part of the Thematic Series "Functional materials for environmental sensors and energy systems".

Guest Editor: M. Penza

(C) 2017 Al-Mayman et al.; licensee Beilstein-Institut. License and terms: see end of document.

\begin{abstract}
Fly ash from power plants is very toxic because it contains heavy metals. In this study fly ash was treated with a thermal plasma. Before their treatment, the fly ash was analyzed by many technics such as X-ray fluorescence, CHN elemental analysis, inductively coupled plasma atomic emission spectroscopy and scanning electron microscopy. With these technics, the composition, the chemical and physical proprieties of fly ash are determined. The results obtained by these analysis show that fly ash is mainly composed of carbon, and it contains also sulfur and metals such as $\mathrm{V}, \mathrm{Ca}, \mathrm{Mg}, \mathrm{Na}, \mathrm{Fe}, \mathrm{Ni}$, and $\mathrm{Rh}$. The scanning electron microscopy analysis shows that fly ash particles are porous and have very irregular shapes with particle sizes of $20-50 \mu \mathrm{m}$. The treatment of fly ash was carried out in a plasma reactor and in two steps. In the first step, fly ash was treated in a pyrolysis/combustion plasma system to reduce the fraction of carbon. In the second step, the product obtained by the combustion of fly ash was vitrified in a plasma furnace. The leaching results show that the fly ash was detoxified by plasma vitrification and the produced slag is amorphous and glassy.
\end{abstract}

\section{Introduction}

Fly ash is a residue material produced in power plants. This fly ash contains a high level of residual carbon [1], and it contains also transition metals ( $\mathrm{Fe}, \mathrm{Mn}$, and $\mathrm{Co}$ ) and alkaline earth metals $(\mathrm{Ba}, \mathrm{Ca}$, and $\mathrm{Mg}$ ). These metals are added to the fuel oils for the suppression of soot or for corrosion control [2,3]. This fly ash is toxic because it contains a high percentage of heavy metals, such as V and Ni. Furthermore, the landfill of fly ash is expensive and causes several environmental problems such as pollution of the soil with organic compounds, leaching of heavy metals and secondary dust generation. Consequently, the treatment of fly ash is an essential process prior to storing it [4].

To treat fly ash many methods have been developed. For example, fly ash was disposed in landfill after being stabilized or immobilized by hydraulic binder [5]. Another technique used to treat the fly ash is thermal plasma. The temperature inside the 
plasma furnace varied between 4000 and $20000 \mathrm{~K}$. At this range of temperatures, all existing substances will be vitrified, reducing the product mass and converting it to a glassy slag with lower leachability than bottle glass [6,7]. For this reason, thermal plasma is a promising technology for the treatment of fly ash [8-10]. Furthermore plasma technology was used to treat the most toxic waste like radioactive wastes, contaminated hospital wastes, and organohalogen wastes [11].

The first objective of the present study was to characterize the fly ash from power plants using heavy fuel oils in Saudi Arabia. After the characterization, the fly ash will be treated by thermal plasma system built in the laboratory at KACST, which is based on plasma arc technology. The second objective of this investigation was to evaluate the process regarding the following parameters: 1) the percentage of reduction in mass and volume of fly ash, 2) the rate of detoxification (removal of hazardous elements) of fly ash and 3) the stability of the produced slag and the behavior of hazardous materials in leaching tests.

\section{Experimental}

\section{Thermal plasma system}

The first step of this work consists of the reduction of volume by combustion of carbon present in fly ash. Figure 1 shows the system based on plasma arc technology used for this step. The thermal plasma system consists of two plasma-reaction chambers, one for pyrolysis and the second for final combustion. The system also contains a loading system, a working gas unit, a cooling water unit, a power supply system, and a gas cleaning system. In the two plasma-reaction chambers, the working gas is air and is injected axially into the two plasma torches at a flow rate of $45 \mathrm{~m}^{3} / \mathrm{h}$. The current intensity and the voltage for the pyrolysis and combustion plasma torches are $100 \mathrm{~A} / 220 \mathrm{~V}$ and $150 \mathrm{~A} / 220 \mathrm{~V}$, respectively. A hydrofilter is used for purification of the exhaust flow from mechanical impurities, sprays, vapors, and gas impurities. The feeder is filled with fly ash, and will mechanically provide for loading $25 \mathrm{~kg} / \mathrm{h}$ into the plasmareaction chamber.

In the second step, the treated fly ash (product) was vitrified in the system shown in Figure 2. The torch was mounted above a crucible filled with the product and a glass frit (to increase the mass of Si in the product). The water-cooled stainless steel crucible is set just under the coupling zone of the plasma torches. During the experiments reported here, the current intensity is $100 \mathrm{~A}$ and the voltage is $220 \mathrm{~V}$. In this step an inert gas (argon) is used as working gas at a flow rate of $45 \mathrm{~m}^{3} / \mathrm{h}$.

\section{Analysis methods}

The surface of the fly ash before (feed) and after treatment (product) were characterized using scanning electron microscopy (FEI INSPECT-F50-SEM, Netherlands). Chemical composition of feed and product were measured by X-ray fluorescence measurements (Shimadzu XRF-1800 Sequential X-Ray Fluorescence Spectrometer, Japan). The carbon content in the feed and the product were determined using a $\mathrm{CHN}$ analyzer (ELTRA CW multiphase-determinator, Germany). The concentrations of elements presents in the feed, product, and the



Figure 1: Pyrolysis/combustion plasma system. 


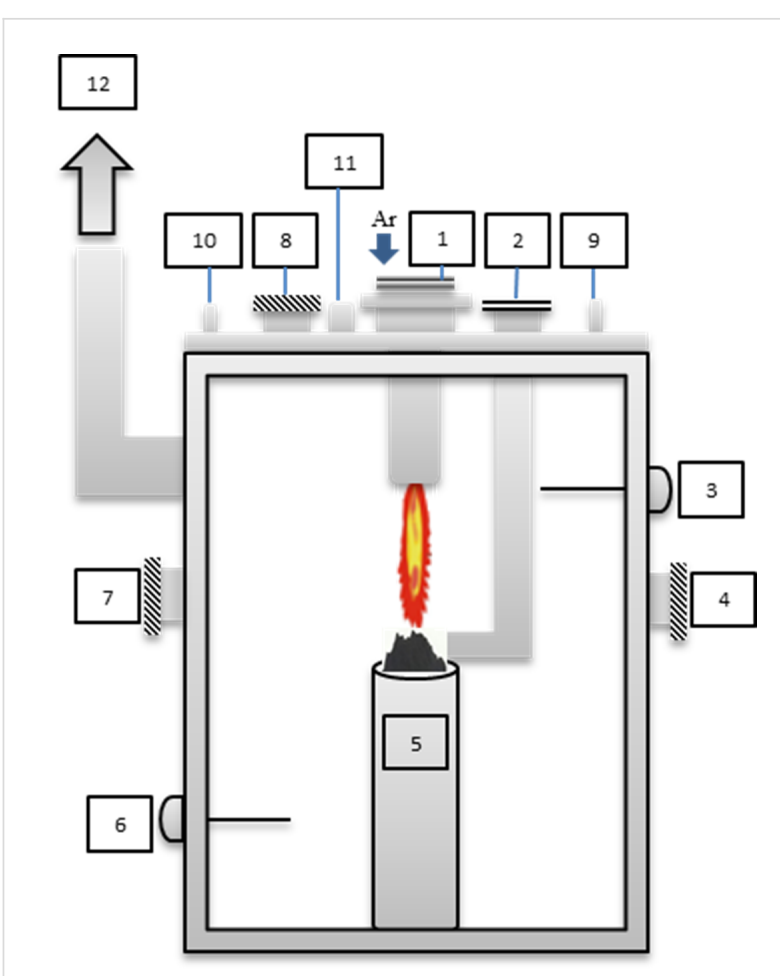

Figure 2: Vitrification plasma system: 1) torch, 2) feeder, 3 and 6 ) thermocouples, 4 and 7) windows, 5) crucible, 8) inspection window, 9) water inlet, 10) water outlet, 11) pressure sensor, 12) exhaust.

pulverized slag were analyzed using inductively coupled plasma atomic emission spectroscopy (ICP-AES). The leaching behavior of heavy metals in the slag and fly ash was measured according to "Method 1311 Toxicity Characteristic Leaching Procedure" of the United States Environmental Protection Agency (EPA TCLP 1311). In the beginning of the leaching analysis, the amount of solids in the sample was specified. A sample that contains less than $0.5 \%$ dry solid material is considered as TCLP extract. The extraction was carried out using acetic acid as TCLP extraction fluid (20 times the weight of the solid phase) for 18 hours on an agitation tumbler (end-over-end shaking speed: $30 \pm 2 \mathrm{rpm}$ ). The extracted fluid was tested by using the extraction fluid buffer while maintaining the $\mathrm{pH}$ value at 4.93. After that, the fluid was filtered through a $0.6 \mu \mathrm{m}$ membrane filter in order to separate the TCLP extract from the solid phase. Finally, the obtained liquid was analyzed by using inductively coupled plasma mass spectroscopy (ICP-MS).

\section{Results and Discussion Characterization of fly ash}

The chemical composition of the feed determined with XRF is presented in Figure 3. The major constituents of the feed are $\mathrm{NiO}, \mathrm{Fe}_{2} \mathrm{O}_{3}, \mathrm{SO}_{3}, \mathrm{~V}_{2} \mathrm{O}_{5}, \mathrm{CaO}, \mathrm{P}_{2} \mathrm{O}_{5}, \mathrm{SrO}$ and $\mathrm{MoO}_{3}$. Table 1 gives the concentration of each element present in the feed measured by ICP-AES. Many elements are not listed in Table 1 because of the very low concentration. These results confirm the XRF analysis. The major constituents $(100-1000 \mathrm{mg} / \mathrm{kg})$ in fly ash samples were $\mathrm{V}, \mathrm{Ca}, \mathrm{Mg}, \mathrm{Na}, \mathrm{Fe}, \mathrm{Ni}$, and $\mathrm{Rh}$. The minor constituents (10-100 mg/kg) include $\mathrm{Br}, \mathrm{Si}$, and $\mathrm{Al}$. The fly ash contains also toxic elements such as $\mathrm{Pb}, \mathrm{As}, \mathrm{Zn}$, and $\mathrm{Cr}$ but with relatively low concentrations.

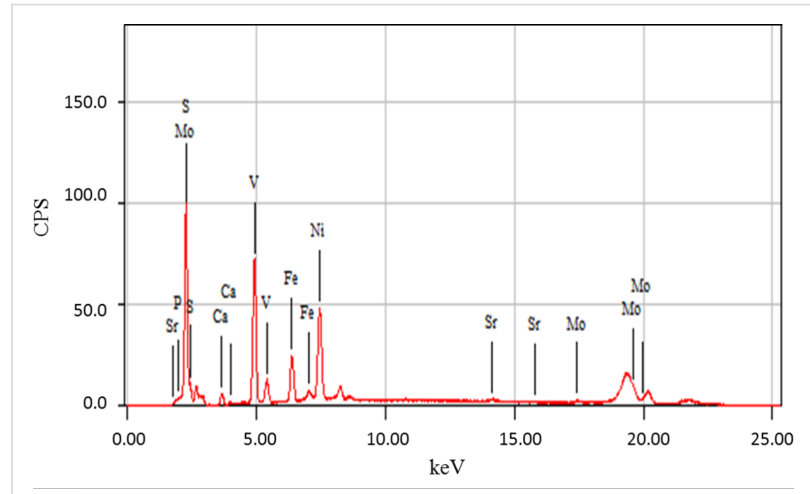

Figure 3: XRF analysis of feed.

In addition, the fly ash samples have been analyzed for carbon, sulfur, nitrogen and hydrogen (CHN elemental analysis). Table 2 shows the results of the fly ash samples. It should be noted that fly ash is black, which indicates a high carbon content $(90.81 \mathrm{wt} \%)$. It also contains a high amount of sulfur (6.17 wt \%).

\begin{tabular}{|c|c|c|c|c|c|c|c|c|c|c|}
\hline element & V & $\mathrm{Ca}$ & $\mathrm{Al}$ & $\mathrm{Mg}$ & $\mathrm{Na}$ & $\mathrm{Fe}$ & $\mathrm{Ni}$ & $\mathrm{Rh}$ & $\mathrm{Br}$ & $\mathrm{Si}$ \\
\hline feed & 952.8 & 910.4 & 39.8 & 495.3 & 319.5 & 106.1 & 82.9 & 72.4 & 61.6 & 49.6 \\
\hline product & 910.4 & 106.1 & 49.6 & 319.5 & 72.4 & 952.8 & 495.3 & 39.8 & 39.2 & 36.4 \\
\hline element & $\mathrm{Zn}$ & $\mathrm{Pb}$ & Mo & $\mathrm{Ba}$ & $\mathrm{K}$ & As & $\mathrm{Sr}$ & $\mathrm{Ti}$ & $\mathrm{Cr}$ & $\mathrm{Mn}$ \\
\hline feed & 39.2 & 36.4 & 8.7 & 7.8 & 7.3 & 6.5 & 6.3 & 2.8 & 2.3 & 1.7 \\
\hline product & 7.8 & 6.3 & 6.5 & 2.8 & 1.7 & 1.6 & 1.1 & 7.3 & 61.6 & 8.7 \\
\hline
\end{tabular}




\begin{tabular}{|c|c|c|c|c|}
\hline & \multicolumn{2}{|c|}{ feed } & \multicolumn{2}{|c|}{ product } \\
\hline & wt \% & atom \% & wt \% & atom $\%$ \\
\hline carbon & 90.81 & 95.20 & 91.12 & 95.71 \\
\hline oxygen & 3.02 & 2.37 & 2.02 & 1.59 \\
\hline hydrogen & 0.074 & 0.072 & 0.064 & 0.053 \\
\hline nitrogen & 0 & 0 & 0 & 0 \\
\hline sulfur & 6.17 & 2.42 & 6.86 & 2.70 \\
\hline
\end{tabular}

\section{Combustion of fly ash}

As indicated in Table 2, fly ash is mainly composed of carbon, sulfur and residue ash, whereas carbon is the dominant element of carbon black. For this reason, the first step of treatment consists of the reduction of the carbon fraction by combustion (Figure 1). In this experiment, $2.4 \mathrm{~kg}$ of feed were introduced in the pyrolysis chamber and only $350 \mathrm{~g}$ of product were collected at the exit of the combustion chamber, which amounts to a reduction of fly ash mass of $85 \%$.

Figure 4 shows the chemical composition of the product obtained by XRF. This analysis shows that the major constituents of the product are the same present in the feed. Also, important contributions of $\mathrm{K}_{2} \mathrm{O}, \mathrm{TiO}_{2}, \mathrm{ZnO}, \mathrm{Cr}_{2} \mathrm{O}_{3}, \mathrm{CuO}$, and $\mathrm{RuO}_{2}$ were detected. The concentrations of product elements measured by ICP-AES are summarized in Table 1.

The product has the same major and minor constituents of the feed (Table 1) and also contains toxic elements. As indicated before, fly ash has a high level of carbon content, and carbon is also the major constituent of the product (91.12 wt \%, Table 2).

Table 3 gives the mass of each element present in the fly ash before and after the treatment by thermal plasma. The element masses are obtained from the concentrations presented in Table 1 and taking into consideration the ratio of fly ash mass to the product mass. The mass of each element in Table 3 is calculated according to the following equation:

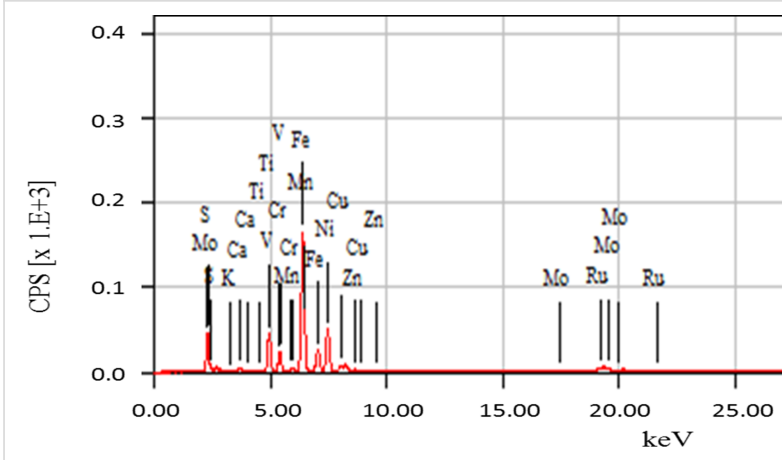

Figure 4: XRF analysis of product.

$$
m_{i}=c_{i} \cdot m_{t}
$$

where $m_{i}$ is the mass of element $(\mathrm{mg}), c_{i}$ is the concentration of the element $(\mathrm{mg} / \mathrm{kg})$ and $m_{t}$ is the mass of fly ash $(\mathrm{kg})$. The mass of fly ash is $2.4 \mathrm{~kg}$ before processing and $0.35 \mathrm{~kg}$ after processing. After the combustion of fly ash the masses of the metals decrease (more than $40 \%$ for $\mathrm{V}$, and more than $90 \%$ for $\mathrm{Ca}$ ). The weights of $\mathrm{Fe}, \mathrm{Cr}$, and $\mathrm{Mn}$ increase because these metals are used as refractory material in the combustion chamber.

SEM images of feed and product are shown in Figure 5. The fly ash has different particle sizes and the particle shapes are not regular. The carbonaceous nature of the feed and product is deduced from the porous particles as viewed in Figure 5 at $500 \times$ and $5000 \times$ magnifications. At 500 $\times$ magnification, highly porous particles of diameters between 20 and $50 \mu \mathrm{m}$ for feed and between 10 and $30 \mu \mathrm{m}$ for product are obtained. At $5000 \times$ magnification, highly porous particles of $d_{\mathrm{p}} \approx 30 \mu \mathrm{m}$ (feed) and $d_{\mathrm{p}} \approx 15 \mu \mathrm{m}$ (product) can clearly be seen. The presence of crystalline phases is detected at $20,000 \times$ magnification at which oxides of $\mathrm{Mg}, \mathrm{V}, \mathrm{Ni}, \mathrm{Fe}$ and $\mathrm{S}$ appear as plates [12-14].

\section{Vitrification and leaching of metals}

The product was subsequently vitrified in the system shown in Figure 2. To increase the Si content, $1 \mathrm{~kg}$ of glass frit was added to $1 \mathrm{~kg}$ of the product. Figure 6 shows a photograph of fly ash

Table 3: Mass $(\mathrm{mg})$ of each elements present in the fly ash before and after treatment by combustion/pyrolysis plasma. The masses were calculated from Table 1 and using Equation 1.

\begin{tabular}{|c|c|c|c|c|c|c|c|c|c|c|}
\hline element & V & $\mathrm{Ca}$ & $\mathrm{Mg}$ & $\mathrm{Na}$ & $\mathrm{Fe}$ & $\mathrm{Ni}$ & $\mathrm{Rh}$ & $\mathrm{Br}$ & $\mathrm{Si}$ & $\mathrm{Al}$ \\
\hline feed & 777.46 & 519.93 & 331.661 & 288.61 & 256.01 & 247.12 & 133.46 & 86.161 & 55.359 & 34.422 \\
\hline product & 455.22 & 53.089 & 159.75 & 36.24 & 476.43 & 247.65 & 19.92 & 19.62 & 18.22 & 24.80 \\
\hline element & $\mathrm{Zn}$ & $\mathrm{Pb}$ & Mo & $\mathrm{Ba}$ & $\mathrm{K}$ & As & $\mathrm{Sr}$ & $\mathrm{Ti}$ & $\mathrm{Cr}$ & $\mathrm{Mn}$ \\
\hline feed & 11.12 & 8.41 & 7.95 & 6.36 & 5.75 & 5.47 & 5.18 & 4.96 & 3.03 & 1.88 \\
\hline product & 3.92 & 3.18 & 3.25 & 1.42 & 0.85 & 0.83 & 0.54 & 3.66 & 30.82 & 4.36 \\
\hline
\end{tabular}




\section{Feed}
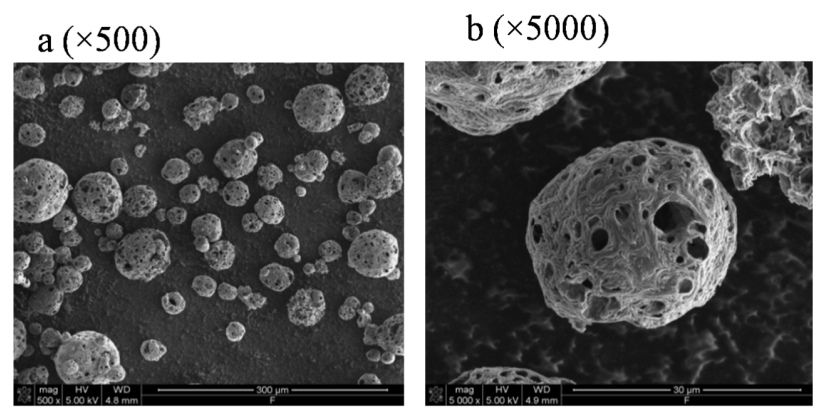

c $(\times 20000)$

Product

a $(\times 500)$

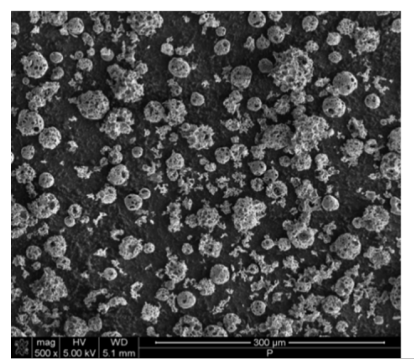

$\mathrm{b}(\times 5000)$

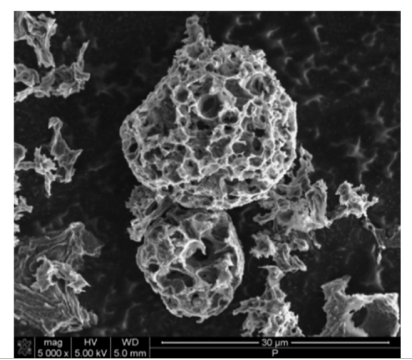

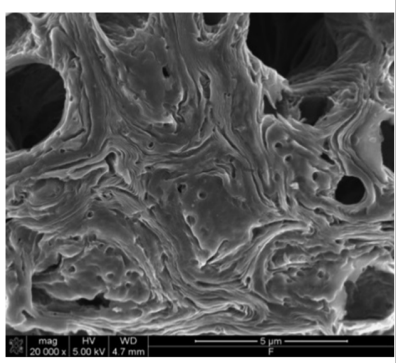

c $(\times 20000)$

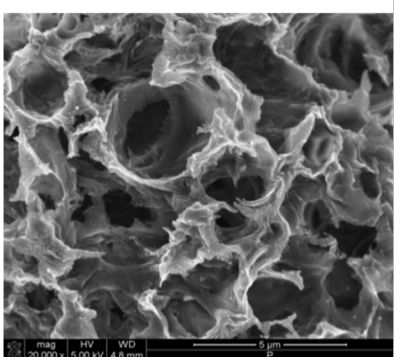

Figure 5: SEM images of feed and product.

and the obtained slag. The produced slag is amorphous and glassy. The hardness and the density of the slag are $5 \mathrm{GPa}$ and $1.69 \mathrm{~g} / \mathrm{cm}^{3}$, respectively.
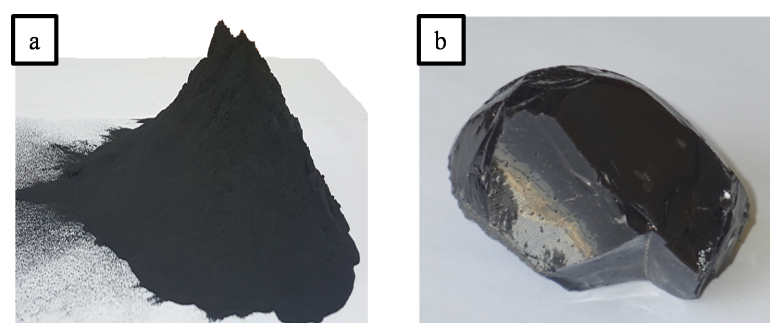

Figure 6: Photographs of a) fly ash and b) vitrified slag.

In order to evaluate the release of heavy metals under harsh environmental conditions, a prolonged leaching test (14 days) was used to investigate the leaching concentrations of heavy metals from the fly ash and the slag, and the results are shown in Table 4. It can be seen that the leaching concentrations of heavy metals from fly ash were much higher than those from slag. The concentrations of the elements present in the slag were compared with the directive of the European Union for landfill for non-toxic materials and the US EPA limits [15]. The results indicated that all the values were much lower than regulatory standard limits and suggested low leaching risk of heavy metals from the slag. So the heavy metals are confined in the silicon matrix and the slag can be disposed in landfill.

\begin{tabular}{|c|c|c|}
\hline \multirow[t]{2}{*}{ element } & \multicolumn{2}{|c|}{ release $\left(\mathrm{mg} \cdot \mathrm{cm}^{-2} \cdot \mathrm{day}^{-1}\right)$} \\
\hline & fly ash & slag \\
\hline lead & 0.753 & 0.019 \\
\hline chromium & 0.006 & 0.001 \\
\hline zinc & 2.7 & 0.0007 \\
\hline arsenic & 0.004 & ND \\
\hline
\end{tabular}

\section{Conclusion}

Fly ash collected in exhaust treatment system of power plants using heavy fuel oils is mainly composed of carbon (90.81 wt \%), sulfur (6.17 wt \%) and residue ash such as V, Ca, $\mathrm{Mg}, \mathrm{Na}, \mathrm{Fe}, \mathrm{Ni}$, and $\mathrm{Rh}$. Fly ash particles are porous, they have very irregular shapes and particle sizes from 20 to $50 \mu \mathrm{m}$. The treatment of the fly ash was made in two steps. In the first one, the fly ash was treated by a pyrolysis/ combustion plasma system. In this phase the weight of the ash was reduced by $85 \%$ and the metals were partially vaporized. In the second step of treatment, the product obtained by the combustion of fly ash was vitrified in a plasma furnace. The produced slag obtained by vitrification of the product is amorphous and glassy. The 
leaching results indicated that all measured values were much lower than regulatory standard limits and suggested a low leaching risk of heavy metals from the slag. So the heavy metals are confined in the silicon matrix and the slag can be disposed in landfill.

\section{Acknowledgements}

This research was performed in the Water \& Energy Research Institute (WERI), at the National Center for Combustion \& Plasma Technology (NCCPT) under the project "Plasma Processing of Fly Ash Resulted from Desalination Plants". King Abdulaziz City for Science \& Technology (KACST), Riyadh, Saudi Arabia is gratefully acknowledged for financial support.

\section{References}

1. Al-Malack, M. H.; Bukhari, A. A.; Al-Amoudi, O. S.; Al-Muhanna, H. H.; Zaidi, T. H. Int. J. Environ. Res. 2013, 7, 455-466.

2. Bulewicz, E. M.; Evans, D. G.; Padley, P. J. Effect of Metallic Additives on Soot Formation Processes in Flames. In Proceedings of the 15th International Symposium on Combustion, The Combustion Institute: Pittsburgh, PA, U.S.A., 1974; pp 1461-1470.

3. Feldman, N. Control of Residual Fuel Oil Particulate Emissions by Additives. In Proceedings of the 19th International Symposium on Combustion, The Combustion Institute: Pittsburgh, PA, U.S.A., 1982; pp 1387-1393. doi:10.1016/s0082-0784(82)80315-9

4. Zacharczuk, W.; Kordylewski, W.; Kasprzyk, K. Arch. Combust. 2003, 23, No. 1-2.

5. Ghiloufi, I.; Baronnet, J. M. High Temp. Mater. Processes (Danbury, CT, U. S.) 2006, 10, 117-139. doi:10.1615/HighTempMatProc.v10.i1.90

6. Tzeng, C.-C.; Kuo, Y.-Y.; Huang, T.-F.; Lin, D.-L.; Yu, Y.-J. J. Hazard. Mater. 1998, 58, 207. doi:10.1016/S0304-3894(97)00132-5

7. Min, B. Y.; Kang, Y.; Song, P. S.; Choi, W. K.; Jung, C. H.; Oh, W. Z. Ind. Eng. Chem. 2007, 13, 57-64.

8. Peng, Z.; Ni, G.; Jiang, Y.; Chen, L.; Chen, M.; Meng, Y. J. Hazard. Mater. 2010, 181, 580-585. doi:10.1016/j.jhazmat.2010.05.052

9. Ghiloufi, I. Electronic Waste Treatment by Thermal Plasma. E-Waste: Management, Types and Challenges; Nova Science Publishers, Inc.: Hauppauge, NY, U.S.A., 2012; pp 169-204.

10. Wang, Q.; Yan, J.; Tu, X.; Chi, Y.; Li, X.; Lu, S.; Cen, K. Fuel 2009, 88, 955-958. doi:10.1016/j.fuel.2008.12.011

11. Ghiloufi, I.; Amouroux, J. High Temp. Mater. Processes (Danbury, CT, U. S.) 2010, 14, 77-88. doi:10.1615/HighTempMatProc.v14.i1-2.60

12. Sarkar, A.; Rano, R.; Udaybhanu, G.; Basu, A. K. Fuel Process. Technol. 2006, 87, 259-277. doi:10.1016/j.fuproc.2005.09.005

13. Marrero, J.; Polla, G.; Rebagliati, R. J.; Plá, R.; Gómez, D.; Smichowski, P. Spectrochim. Acta, Part B 2007, 62, 101-108. doi:10.1016/j.sab.2007.01.007

14. Chancey, R. T.; Stutzman, P.; Juenger, M. C. G.; Fowler, D. W. Cem. Concr. Res. 2010, 40, 146-156. doi:10.1016/j.cemconres.2009.08.029

15. Wu, K.; Shi, H.; Guo, X. Waste Manage. (Oxford, U. K.) 2011, 31 , 2001-2008. doi:10.1016/j.wasman.2011.04.022

\section{License and Terms}

This is an Open Access article under the terms of the Creative Commons Attribution License (http://creativecommons.org/licenses/by/4.0), which permits unrestricted use, distribution, and reproduction in any medium, provided the original work is properly cited.

The license is subject to the Beilstein Journal of Nanotechnology terms and conditions: (http://www.beilstein-journals.org/bjnano)

The definitive version of this article is the electronic one which can be found at:

doi:10.3762/bjnano.8.105 